\title{
Factor VIII R:Ag as a prognostic parameter in intracranial haemorrhage
}

\author{
W S ALMAANI,* A S AWIDI, $\dagger$ M Z KARMI* \\ From the Departments of Neurosurgery, ${ }^{*}$ and Hematology, $\dagger$ Faculty of Medicine, University of Jordan, \\ Amman, Jordan
}

SUMMARY Factor VIII R:Ag was measured serially in 42 patients who had intracranial haemorrhage. It was found that the factor decreased or remained static in the 24 patients who improved $(p<0.025)$, while it increased in the 18 who died $(p<0.0005)$. It is suggested that this factor can be used as a prognostic parameter to predict the outcome after intracranial haemorrhage.

Factor VIII circulates in the plasma as a complex composed of two components: factor VIII:C, which has the clotting activity, and factor VIII R:Ag, or von Willebrand's Factor, which is responsible for platelet adhesiveness to subendothelium. ${ }^{1}$ Factor VIII R:Ag is synthesised mainly by endothelial cells and megakaryocytes. ${ }^{2-5}$ It is released from endothelial cells into the blood stream in response to certain stimuli, such as venous occlusion, exercise, infusion of adrenaline, nicotinic acid, vasopressin and 1-deamino-8-D arginine vasopressin (DDAVP). ${ }^{67} \mathrm{~A}$ rise in factor VIII R:Ag level is noticed after pneumoencephalography and electro-shock which is not blocked by beta blockers. ${ }^{89}$ It is also seen in glomerulonephritis, pre-eclampsia and in limb ischaemia in diabetes. ${ }^{10}$

Since all parameters used to assess the prognosis in intracranial haemorrhage are either clinical or radiological, ${ }^{11}$ and since there are no chemically measurable substances to achieve this, we decided to study the value of factor VIII R:Ag in this respect. The aim was to determine the changes of factor VIII $\mathrm{R}: \mathrm{Ag}$ in cases of intracranial haemorrhage and to study prospectively whether it can be used as a prognostic factor in the determination of the outcome in patients afflected with such haemorrhage, and to do so as early as possible in the course of the disease.

Address for reprint requests: W S Almaani FRCSEd, Chief of Neurosurgery, Jordan University Hospital, PO Box 13046, Amman, Jordan.

Received 6 September 1985 and in revised form 30 January 1986. Accepted 24 March 1986

\section{Patients and methods}

This study was prospective and concerned 62 patients who were admitted to the Jordan University Hospital (JUH) in the years 1983, 1984 and 1985. All patients with suspected CNS bleeding were subjected to computed tomography (CT) on admission, and those with proven CNS bleeding were admitted to the study. All patients were examined by the three authors daily until discharge or death, and all relevant information was thus recorded.

On admission a full "coagulation screen" was performed on each patient, and consisted of: (1) Bleeding time by the Ivy method using simplate-II device (General Diagnostics, New Jersey, USA), (2) Prothrombin time and partial thromboplastin time (Orthodiagnostics, Raritan, New Jersey, USA), (3) Plasma fibrinogen by electro-immunoassay using commercial antisera (Hoechst, Frankfurt/Main, West Germany), and (4) Manual platelet count. In addition the plasma was tested on the first and third days following admission for factor VIII R:Ag and factor VIII:C as previously described. ${ }^{12}$

\section{Results}

Sixty two patients were studied, 20 of whom were excluded: ten because of underlying haemostatic defect (table 1), four because of disseminated intra-

Table 1 Underlying haemostatic defect: patients excluded from the study

\begin{tabular}{lc}
\hline Haemostatic defect & No \\
\hline Acquired platelet dysfunction & 1 \\
Acquired vitamin K deficiency & 2 \\
Idiopathic thrombocytopenic purpura & 1 \\
von Willebrand's disease & 4 \\
Hypofibrinogenaemia & 2 \\
Total & 10 \\
\hline
\end{tabular}


Table 2 Causes of intracranial haemorrhage after exclusion of patients with underlying haemostatic defect

\begin{tabular}{|c|c|c|c|c|c|c|c|c|}
\hline \multirow[b]{2}{*}{ Cause } & \multicolumn{4}{|c|}{ Male } & \multicolumn{4}{|c|}{ Female } \\
\hline & No & Dead & Alive & $A g e^{*}(y r)$ & No & Dead & Alive & $\operatorname{Age}^{*}(y r)$ \\
\hline $\begin{array}{l}\text { Trauma } \\
\text { Hypertension } \\
\text { Primary } \\
\text { Aneurysmal } \\
\text { Total }\end{array}$ & $\begin{array}{r}7 \\
10 \\
5 \\
2 \\
24\end{array}$ & $\begin{array}{r}3 \\
6 \\
1 \\
1 \\
11\end{array}$ & $\begin{array}{r}4 \\
4 \\
4 \\
1 \\
13\end{array}$ & $\begin{array}{l}52 \cdot 4 \\
53 \cdot 7 \\
25 \cdot 3 \\
20 \cdot 5 \\
44 \cdot 6\end{array}$ & $\begin{array}{r}2 \\
7 \\
6 \\
3 \\
18\end{array}$ & $\begin{array}{l}1 \\
4 \\
2 \\
0 \\
7\end{array}$ & $\begin{array}{r}1 \\
3 \\
4 \\
3 \\
11\end{array}$ & $\begin{array}{l}30 \cdot 5 \\
47 \cdot 9 \\
29 \cdot 1 \\
35 \cdot 2 \\
37 \cdot 6\end{array}$ \\
\hline
\end{tabular}

*Mean.

Table 3 The values of factor VIII R:Ag in the first group (alive) as measured on day 1 and day 3 post ictus

\begin{tabular}{|c|c|c|c|c|c|}
\hline Patient No & $\begin{array}{l}R: A g \text { value* } \\
(\text { Day } I)\end{array}$ & $\begin{array}{l}R: A g \text { value* } \\
\text { (Day 3) }\end{array}$ & Patient No & $\begin{array}{l}\text { R:Ag value* } \\
\text { (Day 1) }\end{array}$ & $\begin{array}{l}\text { R:Ag value } \\
\text { (Day 3) }\end{array}$ \\
\hline $\begin{array}{r}1 \\
2 \\
3 \\
4 \\
5 \\
6 \\
7 \\
8 \\
9 \\
10 \\
11 \\
12\end{array}$ & $\begin{array}{l}520 \\
680 \\
218 \\
520 \\
412 \\
420 \\
150 \\
534 \\
450 \\
750 \\
400 \\
225\end{array}$ & $\begin{array}{l}520 \\
580 \\
180 \\
420 \\
412 \\
360 \\
150 \\
160 \\
450 \\
450 \\
300 \\
225\end{array}$ & $\begin{array}{l}13 \\
14 \\
15 \\
16 \\
17 \\
18 \\
19 \\
20 \\
21 \\
22 \\
23 \\
24\end{array}$ & $\begin{array}{l}200 \\
250 \\
246 \\
194 \\
600 \\
339 \\
412 \\
460 \\
400 \\
360 \\
220 \\
250\end{array}$ & $\begin{array}{l}134 \\
134 \\
130 \\
115 \\
480 \\
259 \\
332 \\
382 \\
325 \\
275 \\
141 \\
175\end{array}$ \\
\hline
\end{tabular}

*Percent of normal.

Mean 干 SD (Day 1) : $383.75 \mp 161.95$

Mean $\mp$ SD (Day 3) : $295 \cdot 38 \mp 142 \cdot 37$

$\mathrm{p}<0.025$

Table 4 The values of factor VIII R:Ag in the second group (dead) as measured on day 1 and day 3 post ictus

\begin{tabular}{|c|c|c|c|c|c|}
\hline Patient No & $\begin{array}{l}\text { R:Ag value* } \\
\text { (Day 1) }\end{array}$ & $\begin{array}{l}\text { R:Ag value* } \\
\text { (Day 3) }\end{array}$ & Patient No & $\begin{array}{l}R: A g \text { value* } \\
\text { (Day 1) }\end{array}$ & $\begin{array}{l}\text { R:Ag value* } \\
\text { (Day 3) }\end{array}$ \\
\hline $\begin{array}{l}1 \\
2 \\
3 \\
4 \\
5 \\
6 \\
7 \\
8 \\
9\end{array}$ & $\begin{array}{l}520 \\
420 \\
200 \\
360 \\
400 \\
412 \\
360 \\
400 \\
360\end{array}$ & $\begin{array}{l}750 \\
550 \\
620 \\
550 \\
800 \\
612 \\
548 \\
525 \\
630\end{array}$ & $\begin{array}{l}10 \\
11 \\
12 \\
13 \\
14 \\
15 \\
16 \\
17 \\
18\end{array}$ & $\begin{array}{l}160 \\
330 \\
254 \\
200 \\
312 \\
250 \\
235 \\
200 \\
303\end{array}$ & $\begin{array}{l}250 \\
630 \\
354 \\
286 \\
522 \\
460 \\
445 \\
410 \\
516\end{array}$ \\
\hline
\end{tabular}

*Percent of normal.

Mean $\mp$ SD (Day 1) : $315 \cdot 33 \mp 97.44$

Mean $\mp$ SD (Day 3): $525.44 \mp 144.02$

$\mathrm{p}<0.0005$

vascular clotting (DIC), and six because of sampling error. Of the remaining 42 patients 24 were males (mean age 44.63 years $\mp 20 \cdot 13$ SD) and 18 females (mean age 37.58 years $\mp 17.36 \mathrm{SD}$ ). The causes of bleeding are shown in table 2 . We divided the patients into two prognostic categories: alive and dead (hereafter called group 1 and group 2 respectively).

Factor VIII R:Ag values on admission in group 1 varied between $150 \%$ and $750 \%$ (normal $100 \%$ ) with a mean of 383.75 and SD $\mp 161.95$, and on day three it varied between $115 \%$ and $550 \%$ with a mean of
295.38 and SD $\mp 142 \cdot 37$, (table 3). In group 2 the values varied on admission between $160 \%$ and $520 \%$ with a mean of 315.33 and SD $\mp 97.44$ and on the third day they varied between $250 \%$ and $800 \%$ with a mean of 525.44 and SD $\mp 144.02$, (table 4).

It can be seen clearly from figs 1 and 2 that there was a significant decline in the factor VIII R:Ag values for the first group between day one and three $(p<0.025)$, whereas there was a significant rise in the factor VIII R:Ag values for the second group between day one and day three $(p<0.0005)$. 


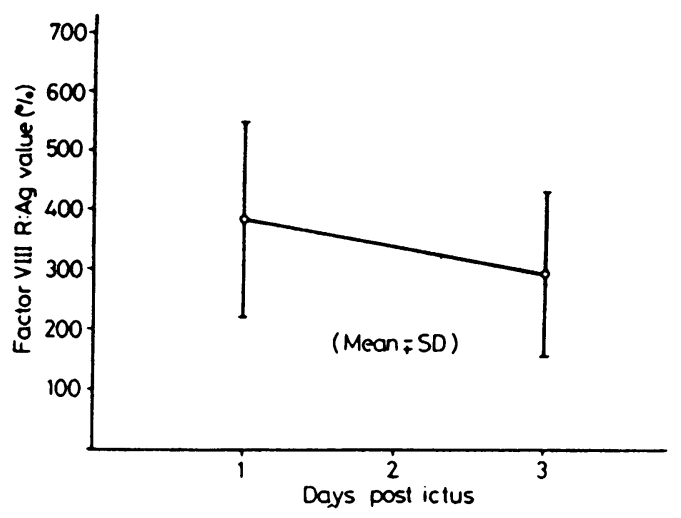

Fig 1 The variation in the values of factor VIII R: Ag between day one and day three in group $1(p<0.025)$.

\section{Discussion}

Since all available parameters used as prognostic indicators in intracranial haemorrhage are either clinical or radiological, ${ }^{11}$ we aimed at identifying a chemically measurable substance that would predict prognosis in this common disease early in its course, rather than wait for longer periods awaiting changes in the clinical status of the patient or subjecting him to repeated investigations.

Factor VIII R:Ag was selected as a potential substance because: (1) it is synthesised by the vascular

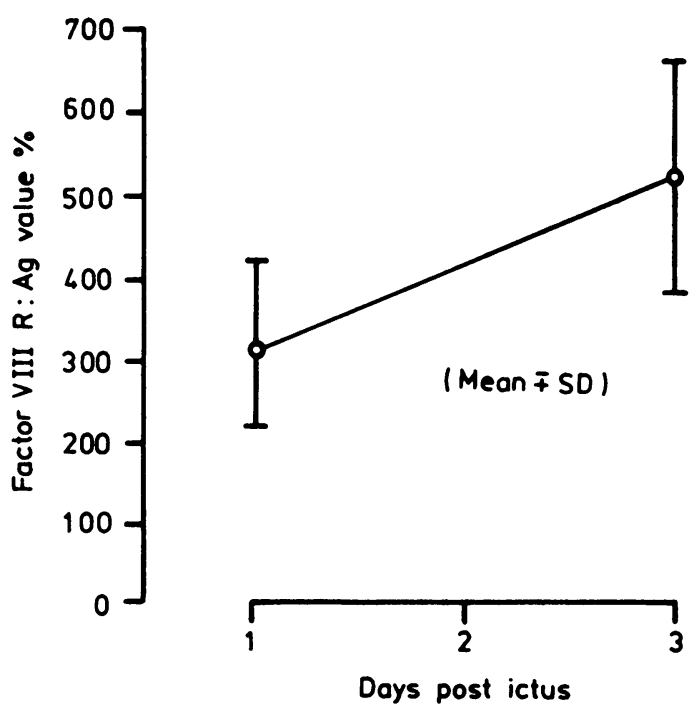

Fig 2 The variation in the values of factor VIII R: Ag between day one and day three in group $2(p<0.0005)$. endothelium, ${ }^{2-5}$ (2) it is known to increase after many CNS insults, ${ }^{6-9}(3)$ it is easily measured with a half life of 12 hours.

We found that factor VIII R:Ag decreased or remained static in all those who showed clinical improvement $(p<0.025)$ irrespective of their initial presenting clinical condition, whereas it increased in all those who died $(p<0.0005)$, again irrespective of their initial clinical status. It is suggested that the increase in factor VIII R:Ag values indicates a continuous or repeated endothelial injury or stimulation reflecting a continuous or repeated CNS damage. It is suggested that the decrease in factor VIII R:Ag values indicates a cessation of the endothelial injury or stimulation reflecting an arrest of the CNS insult.

In spite of the statistical significance of the results, we recognise that the patient population is rather small and the study on a larger number of patients is necessary.

It is interesting to note that 10 out of the 62 patients had an underlying haemostatic defect as a cause of their CNS bleeding, a point that emphasises our previous finding in this respect. ${ }^{13}$ It is suggested that all patients with intracranial haemorrhage should have a coagulation study performed as part of their management.

We conclude that the serial measurement of factor VIII R:Ag is a useful new tool in predicting the prognosis in patients afflected with intracranial haemorrhage.

This work was supported by the University of Jordan, grant no $4 / 5 / 82$.

\section{References}

1 Hoyer LW. The factor VIII complex: structure and functions. Blood 1981;58:1-13.

2 Hoyer LW, De Los Santos RP, Hoyer JR. Antihemophilic factor antigen: localisation in endothelial cells by immunoflurescent microscopy. J Clin Invest 1973;52:2737-44.

3 Bloom AL, Giddings JC, Wilks CJ. Factor VIII on the vascular intima: possible importance in hemostasis and thrombosis. Nature 1973;241:217-9.

4 Jaffe EA, Hoyer LW, Nachman RL. Synthesis of antihemophilic factor antigen by cultured human endothelial cells. J Clin Invest 1973;52:2757-64.

5 Nachman RL, Levine R, Jaffe EA. Synthesis of factor VIII antigen by cultured guinea pig megakaryocytes. $J$ Clin Invest 1977;60:914-21.

6 Mannucci PM, Aberg M, Nilsson IM, Robertson B. Mechanism of plasminogen activator and factor VIII increase after vasoactive drugs. $\mathrm{Br} J$ Haematol 1975;30:81-3.

7 Mannucci PM, Canciani MT, Rota L, Donovan BS. Response of factor VIII (von Willebrand factor) to DDAVP in healthy subjects and patients with 
haemophilia $A$ and von Willebrand's disease. $B r J$ Haematol 1981;47:283-93.

8 Mannucci PM, Ruggeri ZM, Gagnatelli G. Nervous regulation of factor VIII levels in man. $\mathrm{Br} J$ Haematol 1971;20:195-207.

9 Bennett B, Ratnoff OD. Changes in antihemophilic factor (AHF) procoagulant activity and AHF-like antigen in normal pregnancy and following exercise and pneumoencephalography. J Lab Clin Med 1972;80:256-63.

10 Bloom AL. Biosynthesis of factor VIII. Clin Haematol
1979;8:53-77.

11 Helweg-Larsen S, Sommer W, Strange P, Lester J, Boysen G. Prognosis of patients treated conservatively for spontaneous intracerebral hematomas. Stroke 1984;15(6):1045-8.

12 Awidi AS. Congenital hemorrhagic syndromes in Jordan. Thromb Haemost 1984;51:531-4.

13 Almaani WS, Awidi AS. Spontaneous intracranial bleeding in haemorrhagic diathesis. Surg Neurol 1982;17: 137-40. 